\title{
In vivo measurements of lead in bone at four anatomical sites: long term occupational and consequent endogenous exposure
}

\author{
J Erkkilä, R Armstrong, V Riihimäki, D R Chettle, A Paakkari, M Scott, L Somervaille, \\ J Starck, B Kock, A Aitio
}

\begin{abstract}
Measurements of bone lead concentrations in the tibia, wrist, sternum, and calcaneus were performed in vivo by $\boldsymbol{x}$ ray fluorescence on active and retired lead workers from two acid battery factories, office personnel in the two factories under study, and control subjects. Altogether 171 persons were included. Lead concentrations in the tibia and ulna (representative of cortical bone) appeared to behave similarly with respect to time but the ulnar measurement was much less precise. In an analogous fashion, lead in the calcaneus and sternum (representative of trabecular bone) behaved in the same way, but sternal measurement was less precise. Groups occupationally exposed to lead were well separated from the office workers and the controls on the basis of calculated skeletal lead burdens, whereas the differences in blood lead concentrations were not as great, suggesting that the use of concentrations of lead in blood might seriously underestimate lead body burden. The exposures encountered in the study were modest, however. The mean blood lead value among active lead workers was $1.45 \mu \mathrm{mol} \mathrm{l}^{-1}$ and the mean tibial lead concentration $21 \cdot 1 \mu \mathrm{g}$ ( $\mathrm{g}$ bone mineral $)^{-1}$. The kinetics of lead in the tibia appeared to be noticeably different from that in the calcaneus. Tibial lead concentration increased consistently both as a function of intensity of exposure and of duration of ex-
\end{abstract}

\footnotetext{
Institute of Occupational Health, SF-00290 Helsinki, Finland

J Erkkilä, V Riihimäki, A Paakkari, J Starck, A Aitio Medical Physics Group, School of Physics and Space Research, University of Birmingham, Birmingham B15 2TT, England

R Armstrong, D R Chettle, M Scott, L Somervaille South Saimaa Central Hospital, Lappeenranta, Finland

B Kock
}

posure. Calcaneal lead concentration, by contrast, was strongly dependent on the intensity rather than duration of exposure. This indicated that the biological half life of lead in calcaneus was less than the seven to eight year periods into which the duration of exposure was split. Findings for retired workers clearly showed that endogenous exposure to lead arising from skeletal burdens accumulated over a working lifetime can easily produce the dominant contribution to systemic lead concentrations once occupational exposure has ceased.

Lead is a widely used toxic metal that accumulates in the body. It is concentrated in bone, which contains over $90 \%$ of the body burden in adults. $^{1}$ Occupational exposure to lead is routinely monitored by determination of blood lead concentrations, which largely reflect recent average exposure as the half life of lead in blood is of the order of 35 days. ${ }^{2}$ Blood lead concentration has been shown to be associated with indicators of adverse effects on haem synthesis, such as free erythrocyte protoporphyrin, ${ }^{3}$ and with neurophysiological ${ }^{4}$ and psychological effects. $^{56}$

The relation between blood lead concentration and exposure is, however, not necessarily linear ${ }^{7}$ and, in particular, it has been recognised that in a model of a skeletal subcompartment, the lead should be considered readily exchangeable and constitute an intrinsic source of lead input to the blood. ${ }^{289}$ In this context, a measurement of the concentration of bone lead may help to distinguish between recent absorption and endogenous release among subjects with high concentrations of blood lead.

Previous studies on in vivo measurement of lead in finger bones ${ }^{10}$ and in tibia ${ }^{11}$ have shown a close relation between bone lead concentration and time integrated blood lead concentration used as an estimate of cumulative exposure. Such in vivo measurements are therefore gaining acceptance as a valuable tool that enables relations between 
exposures to lead and chronic effects on health to be explored in cross sectional studies. ${ }^{69}$

The aims of our study included the extension of earlier work by measuring the concentration of lead in bone at four different anatomical sites to examine possible variations in the way lead behaves in different types of bone. One bone site was the anterior aspect of the middle of the tibia, because this is largely cortical, is superficial, has a substantial mineral content, and has been measured in many previous studies. ${ }^{11-15}$ The calcaneus was chosen because it is predominantly trabecular and it is also superficial and substantial; a second mainly trabecular bone, the sternum, was selected because its structural function in the skeleton and its load bearing properties are very different from the calcaneus. The mineral content in the sternum is, however, significantly lower than in the calcaneus. Two alternative trabecular bone sites, vertebra and rib, were considered, but had to be rejected; the vertebra because the $x$ ray fluorescence measurement would be dominated by the cortical spinal processes rather than by trabecular bone, and the rib because its mineral content would be too small to give acceptable precision. Problems would also be caused by movement due to normal breathing. The fourth bone site chosen was the distal end of the wrist, which could be expected to contain a mixture of both cortical and trabecular bone.

The study population was selected to encompass a wide range of exposures. People occupationally exposed to lead, both currently and in the past, were measured, together with referent groups drawn firstly from the factory environment and, secondly, from those exposed only to concentrations found in the general urban environment in southern Finland. Within this population, it was intended to study relations among parameters that could be expected to respond to exposure to lead over a range of time scales. The time weighted average blood lead concentration (indicating average intensity of exposure) was determined, as was the time integrated blood lead concentration (reflecting cumulative exposure). These were to be compared with urinary lead and protoporphyrin concentrations as well as the in vivo determination of bone lead concentration. The overall aim was to explore further the role of monitoring of bone lead and its interpretation, considering also its possible relation with endogenous release of lead. Lead exposure has been associated with kidney damage ${ }^{16}$; therefore, the excretion of retinol binding protein and $\mathrm{N}$-acetylglycosaminidase in the urine was measured to study this association further.

\section{Subjects and methods SUBJECTS}

The subjects were divided into four groups according to their histories of exposure (table 1). The groups were (1) currently exposed lead factory workers, (2) former lead workers whose occupational exposure had ceased, (3) office workers within the lead factories, and (4) a control group with no known industrial exposure.

The currently exposed group consisted of occupationally exposed lead workers and foremen, whose blood lead concentrations were monitored regularly. The sample comprised 87 workers at two lead acid battery factories, 53 from the first and 34 from the second, whose main exposure was to metallic lead and lead oxide. Also, there were four workers who handled scrap metallic lead and who were mainly exposed to the dust and fumes of lead. The mean age of these 91 lead workers was 41 (SD 9) years and their duration of exposure was 12 (SD 8) years. There were 74 men and 17 women in this group, the women having a slightly higher mean age of $46 \cdot 1$ years compared with $39 \cdot 3$ years for the men. This difference reflected the companies' preference for not employing women of child bearing age for jobs with exposure to lead.

The formerly exposed lead workers had all been previously employed at one of the two lead acid battery factories, nine at the first and seven at the second. This group had also been monitored by regular determination of blood lead concentrations and their mean duration and intensity of exposure was similar to that of the current workers. The former worker group consisted of 12 men and four women. Their mean age was 56 (SD 7) years, duration of exposure 15 (SD 8) years, and they had ceased occupational exposure to lead for an average of 3.1 years (median two years). All of these people had stopped working with lead before the normal age of retirement ( 65 years); the reasons varied, but only in one case was lead implicated in the person's inability to continue normal working.

The factory office workers, 19 men and 19 women, were secretarial, accountancy, sales, and computer staff whose offices were separated from the battery production areas, so that their exposure to lead was minor compared with the shop floor workers. In consequence, their blood lead concentrations had not been monitored regularly. Their mean age was 41 (SD 9) years and their mean duration of employment at the factory 11 (SD 9) years.

The control group consisted of 16 men and 10 women working at the Institute of Occupational Health in Helsinki. They had had no known occupational exposure to lead, so they were exposed to lead only through the general environment in southern Finland. Their mean age was 36 (SD 9) years.

\section{ANALYSIS OF LEAD IN BONE}

Concentrations of lead in bone were measured in vivo by $x$ ray fluorescence, exciting the lead $\mathrm{K}$-series $x$ rays using the $88 \mathrm{keV} \gamma$ rays from ${ }^{109} \mathrm{Cd} .{ }^{17-20}$ In this 
Table 1 Parameters of lead exposure and other subject characteristics in study groups

\begin{tabular}{|c|c|c|c|c|c|c|c|}
\hline \multirow[b]{4}{*}{ Age (y) } & \multicolumn{7}{|l|}{ Subject category } \\
\hline & \multirow{2}{*}{$\frac{\begin{array}{l}\text { Lead } \\
\text { workers }\end{array}}{\prod_{n}^{\text {Mean }(S D)}}$} & \multicolumn{2}{|c|}{ Former lead workers } & \multicolumn{2}{|l|}{ Office workers } & \multicolumn{2}{|l|}{ Controls } \\
\hline & & $\underset{n}{\operatorname{Mean}}(S D)$ & $\begin{array}{l}\text { Significance } \\
\text { level }\end{array}$ & $\underset{n}{\operatorname{Mean}(S D)}$ & $\begin{array}{l}\text { Significance } \\
\text { level }\end{array}$ & $\underset{n}{\operatorname{Mean}}(S D)$ & $\begin{array}{l}\text { Significance } \\
\text { level }\end{array}$ \\
\hline & $\begin{array}{ll}40 \cdot 6 & (8 \cdot 8) \\
91 & \end{array}$ & $\begin{array}{l}56 \cdot 6 \quad(7 \cdot 5) \\
16\end{array}$ & $\star \star \star$ & $\begin{array}{ll}40 \cdot 8 & (8 \cdot 8) \\
38 & \end{array}$ & $\overline{t+t}$ & $\begin{array}{ll}35 \cdot 9 & (8 \cdot 6) \\
26 & \end{array}$ & $\stackrel{t}{t+1}$ \\
\hline Exposure time (y) & $\begin{array}{ll}12 \cdot 2 & (8 \cdot 4) \\
91 & \end{array}$ & $\begin{array}{l}15 \cdot 4 \quad(7 \cdot 4) \\
16\end{array}$ & - & $\begin{array}{ll}10 \cdot 8 & (9 \cdot 1) \\
37 & \end{array}$ & & & \\
\hline Blood lead $\left(\mu \mathrm{mol} \mathrm{1^{-1 }}\right)$ & $\begin{array}{l}1.45(0.46) \\
91\end{array}$ & $\begin{array}{l}0.59(0.30) \\
16\end{array}$ & $\star \star \star$ & $\begin{array}{l}0.31(0.16) \\
35\end{array}$ & $\begin{array}{l}\star \star \star \\
\dagger \dagger\end{array}$ & $\begin{array}{l}0.18(0.08) \\
23\end{array}$ & $\begin{array}{l}\star \star \star \\
+t \dagger \\
+t+\end{array}$ \\
\hline Urinary lead $\left(\mu \mathrm{mol} \mathrm{l}^{-1}\right)$ & $\begin{array}{l}0.21(0.12) \\
86\end{array}$ & $\begin{array}{l}0.06(0.03) \\
16\end{array}$ & $\star \star \star$ & $\begin{array}{l}0.04(0.03) \\
36\end{array}$ & $\begin{array}{l}\star \star \star \\
\dagger\end{array}$ & $\begin{array}{l}0.02(0.01) \\
21\end{array}$ & $\begin{array}{l}\star \star \star \\
\dagger+\dagger \\
t+\ddagger\end{array}$ \\
\hline $\begin{array}{l}\text { Protoporphyrin IX } \\
\left(\mu \mathrm{mol} 1^{-1}\right)\end{array}$ & $\begin{array}{l}0.62(0.27) \\
78\end{array}$ & $\begin{array}{l}0.45(0.15) \\
16\end{array}$ & $\star \star$ & $27^{0.45(0 \cdot 15)}$ & $\begin{array}{l}\star \star \star \\
-\end{array}$ & $22.45(0.09)$ & $\begin{array}{l}\star \star \star \\
-\end{array}$ \\
\hline $\begin{array}{l}\text { Time weighted average } \\
\text { blood lead }\left(\mu \mathrm{mol} \mathrm{1}^{-1}\right)\end{array}$ & $91^{1.67(0.44)}$ & $13^{1.75(0.64)}$ & - & $2^{0.95}$ & & & \\
\hline $\begin{array}{l}\text { Integrated blood lead } \\
\left(\mu \mathrm{mol} \mathrm{y} 1^{-1}\right)\end{array}$ & $\begin{array}{l}22 \cdot 1(19 \cdot 8) \\
91\end{array}$ & $\begin{array}{l}38 \cdot 8(24 \cdot 5) \\
13\end{array}$ & - & $\begin{array}{c}15 \cdot 5 \\
2\end{array}$ & & & \\
\hline $\begin{array}{l}\text { Tibial lead } \\
\quad\left(\mu \mathrm{g}(\mathrm{g} \text { bone mineral })^{-1}\right)\end{array}$ & $\begin{array}{l}21 \cdot 1(17 \cdot 0) \\
91\end{array}$ & $\begin{array}{l}32 \cdot 4(34 \cdot 9) \\
16\end{array}$ & - & $3^{7 \cdot 7(11 \cdot 3)}$ & $\begin{array}{l}\star \star \star \\
\dagger\end{array}$ & $26^{3.5}(10 \cdot 8)$ & $\begin{array}{l}\star \star \star \\
\dagger \dagger\end{array}$ \\
\hline $\begin{array}{l}\text { Calcaneal lead } \\
\left(\mu \mathrm{g}(\mathrm{g} \text { bone mineral })^{-1}\right)\end{array}$ & $\begin{array}{l}76 \cdot 6(55 \cdot 3) \\
90\end{array}$ & $\begin{array}{l}73 \cdot 5(57 \cdot 7) \\
16\end{array}$ & - & $\begin{array}{l}14 \cdot 2(15 \cdot 6) \\
38\end{array}$ & $\begin{array}{l}\star \star \star \\
\dagger \dagger \dagger\end{array}$ & $\begin{array}{l}1 \cdot 2(10 \cdot 6) \\
24\end{array}$ & $\begin{array}{l}\star \star \star \\
\dagger \dagger \\
\ddagger \dagger\end{array}$ \\
\hline $\begin{array}{l}\text { Sternal lead } \\
\quad\left(\mu \mathrm{g}(\mathrm{g} \text { bone mineral })^{-1}\right)\end{array}$ & $\begin{array}{l}53 \cdot 8(48 \cdot 2) \\
53\end{array}$ & $\begin{array}{l}45 \cdot 3(39 \cdot 8) \\
9\end{array}$ & - & $\begin{array}{l}11.9(16 \cdot 8) \\
21\end{array}$ & $\begin{array}{l}\star \star \star \\
\dagger\end{array}$ & $\begin{array}{c}-10 \cdot 3(28 \cdot 6) \\
21\end{array}$ & $\begin{array}{l}\star \star \star \\
\dagger \dagger \\
\vdots t\end{array}$ \\
\hline $\begin{array}{l}\text { Ulnar lead } \\
\left(\mu \mathrm{g}(\mathrm{g} \text { bone mineral })^{-1}\right)\end{array}$ & $\begin{array}{l}54 \cdot 6(34 \cdot 3) \\
55\end{array}$ & $\begin{array}{l}32 \cdot 9 \\
8\end{array}$ & $\star \star$ & $\begin{array}{l}30 \cdot 0(19 \cdot 5) \\
21\end{array}$ & $\begin{array}{l}\star \star \star \\
-\end{array}$ & $\begin{array}{l}29 \cdot 9(34 \cdot 5) \\
23\end{array}$ & $\stackrel{\star \star}{-}$ \\
\hline $\begin{array}{l}\text { Haemoglobin }\left(\mathrm{gl}^{-1}\right) \text { : } \\
\text { Men } \\
\text { Women }\end{array}$ & $\begin{array}{cl}152 \cdot 4 & (9 \cdot 6) \\
65 & \\
135 \cdot 8 & (7 \cdot 6) \\
17 & \end{array}$ & $\begin{array}{cc}154 & (9 \cdot 8) \\
12 & \\
142 \cdot 5 & (9 \cdot 7) \\
4 & \end{array}$ & - & $\begin{array}{cc}152 \cdot 3 & (12 \cdot 3) \\
12 & \\
136 \cdot 5 & (7 \cdot 6) \\
17 & \end{array}$ & $\begin{array}{l}- \\
-\end{array}$ & $\begin{array}{c}153 \cdot 0(10 \cdot 0) \\
18 \\
135 \cdot 1(10 \cdot 3) \\
10\end{array}$ & $\frac{-}{-}$ \\
\hline
\end{tabular}

Significance levels; ${ }^{\star} p<0.05 ;{ }^{\star \star} p<0.01 ; \star \star \star p p<0.001$ for differences of means from mean of lead workers group. Similarly $\dagger$ for differences of means from former lead workers' group and $\ddagger$ for differences of means from office workers group.

method the background under the lead $\mathrm{K} x$ rays, which principally arises from $\gamma$ rays Compton scattered in the sample, is minimised by adopting a "backscatter" geometry with a source to sample distance of 25 to $30 \mathrm{~mm}$ (fig 1). Figure 2 shows a pulse height spectrum from a phantom measurement. It illustrates the dominance of the Compton scattered background and the separation achieved between this and the lead $x$ rays. Also clearly visible is the peak from elastically (or coherently) scattered $88 \mathrm{keV} \gamma$ rays; this feature is of central importance to this measurement technique because it is produced principally by scattering in the bone mineral matrix in which the lead is also concentrated. Consequently, the ratio of the lead $x$ ray amplitude to the elastic peak amplitude produces an estimate of lead concentration per unit mass of bone mineral, with an accuracy shown to be independent of source to sample distance, thickness of overlying tissue, size of bone measured, source activity, and measurement time. ${ }^{17}$ It is this robustness that makes the method readily usable. Although the accuracy of the technique is not disturbed by the measurement parameters described, the precision does depend on a number of these factors. Precision is therefore improved (measurement uncertainty reduced) by measuring in large bones with high mineral density and by using active sources and long measurement times. Conversely, the thicker the overlying tissue the worse the precision. 


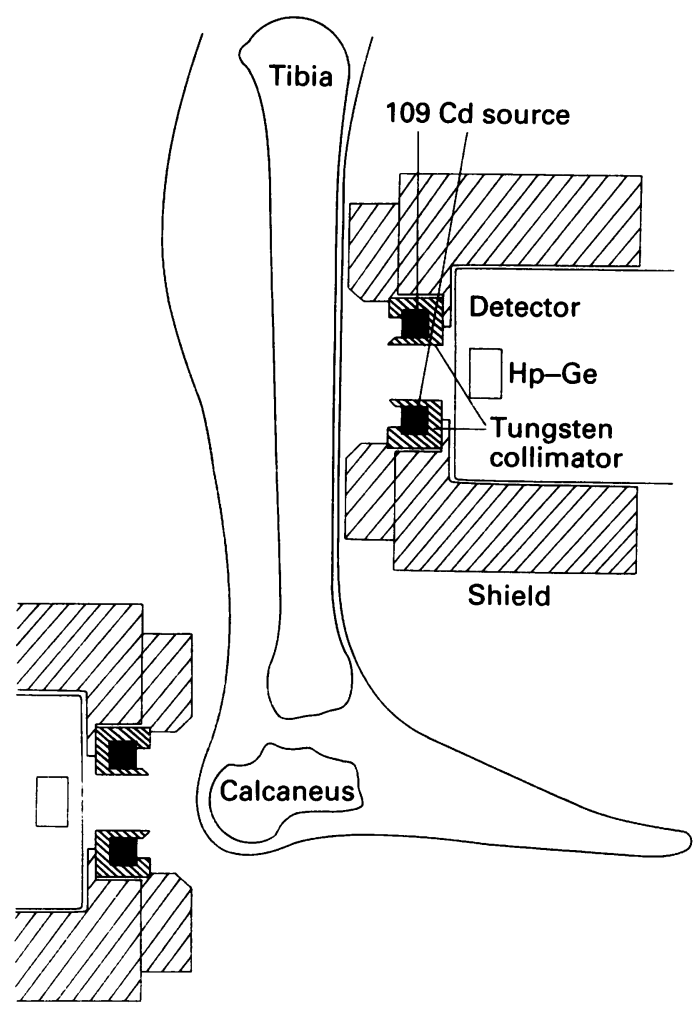

Figure 1 Measurement geometry used for in vivo determination of lead in tibia and calcaneus.

To avoid surface contamination, the skin overlying the bone site in question was washed before each measurement.

EXPOSURE INDICATORS FROM BLOOD SAMPLES

Concentrations of protoporphyrin IX in whole blood were analysed by haematofluorometry ( $\mathrm{ZnP}$ hematofluorometer model 4000, Environmental Sciences Associates, Map, USA). The analytical quality of blood lead determinations was controlled with an external quality assurance scheme. Complete blood lead records for all the currently exposed and 13 of the 16 former lead workers were available and were used to compute time weighted average blood lead concentrations $\left(\mathrm{BPb}_{\text {ave }}\right)$ and time integrated blood lead concentrations $\left(\mathrm{BPb}_{\mathrm{int}}\right)$ as shown later. Lead concentrations in blood and urine were determined using flame methods in the 1960s and 1970s, and graphite furnace AAS methods since the 1980 s. $^{21}$

$$
\begin{aligned}
B P b_{i n t} & =0.5 \times \sum_{i=1}^{n-1}\left(\left(B P b_{i}+B P b_{i+1}\right)\left(t_{i+1}-t_{i}\right)\right) \\
B P b_{a v e} & =\frac{0.5 \times \sum_{i=1}^{n-1}\left(\left(B P b_{i}+B P b_{i+1}\right)\left(t_{i+1}-t_{i}\right)\right)}{\left(t_{n}-t_{1}\right)}
\end{aligned}
$$

where $B P b_{i}$ and $B P b_{i+1}$ are successive determinations of blood lead concentrations on days $t_{i}$ and $t_{i+1}, t_{1}$ is the day on which the first blood sample was collected, and $t_{n}$ that for the last one, which was also the day of the measurement of bone lead concentration. For 86 of 107 current or former workers it was possible to calculate $\mathrm{BPb}_{\text {int }}$ exactly as given in equation (1). The remaining 21 workers (16 current, five no longer exposed) had begun working with lead, however, before regular blood lead monitoring began in 1968 . In most cases the extrapolation to earlier years was performed by averaging the values for 1968 and 1969 (and sometimes 1970) and using this mean value to estimate values for the earlier years. In four cases this strategy was modified because data were not available for 1968 and 1969. For these people $\mathrm{BPb}_{\text {int }}$ was taken simply as $\mathbf{B P b}_{\mathrm{ave}} \times$ duration of exposure.

\section{RENAL EFFECTS}

Urinary $\mathrm{N}$-acetylglucosaminidase activity was determined colorimetrically with 2-methoxy-4-(2'nitrovinyl)phenyl-2-acetamido-2-deoxy- $\beta$-D-glucopyranoside as the substrate (Cortecs Diagnostics, Clwyd, UK), and the concentration of retinol binding protein with the IUPAC proposed standard latex immunoassay method. ${ }^{22}$

\section{QUESTIONNAIRE}

A questionnaire was presented to each subject to elicit general information on place of residence, leisure activities, smoking and alcohol consumption, and dietary habits. More specific enquiry was made of occupational exposure to lead, including duration of exposure and the form of lead involved. Possible exposure to lead in previous jobs was also investigated as was exposure to other heavy metals. The main purpose of the questionnaire was to exclude from the study subjects whose occupational exposure to lead could not reasonably be reconstructed and any people whose biochemical data might have been disturbed for reasons other than their exposure to lead.

\section{STATISTICS}

The data were treated as having a normal linear distribution and SAS statistical software was used in the data analysis. For associations the Pearson product moment correlation was used. Comparisons between groups were performed using the $t$ test with Satterthwaite's approximation for two tailed significance probability. Least squares estimations were applied for regression equations. Analysis of variance was used for the comparisons among multiple groups and variables. Because the group classification schemes divided the data into unbalanced groups, the general linear models procedure was applied with the Tukey option. 


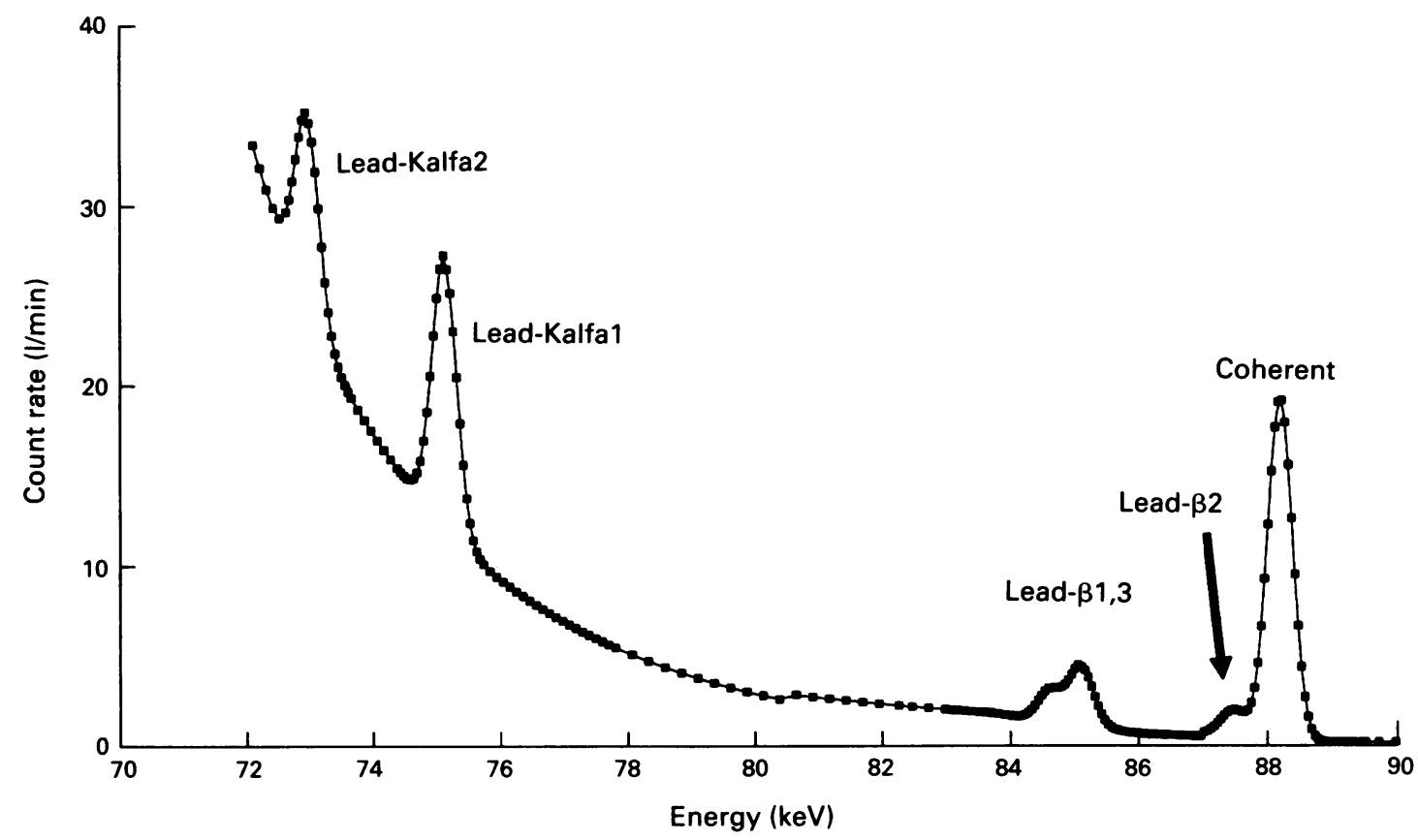

Figure 2 Representative example of pulse high distribution from phantom measurements. Characteristic $x$ ray peaks and the coherent scattering peak are obvious.

\section{MEASUREMENTS}

This study was performed in three phases; in the first phase measurements were made at the first of the two lead acid battery factories ( 53 current, nine former lead workers, 22 factory based office workers) and 22 of the control group were also seen in this period. In this first phase, the group in Helsinki used a single $x$ ray fluorescence apparatus to measure lead in tibia and in ulna sequentially: in each case the measurement time was $1500 \mathrm{~s}$ (live time). The Birmingham group used two sets of $x$ ray fluorescence apparatus to make simultaneous measurements on calcaneus and sternum, the measurement times being $1800 \mathrm{~s}$ (live time). Source activities were all in the range 3.7-7.4 $\mathrm{GBq}$, skin doses at the different sites were in the range 0.8-1.65 mGy, and the total effective dose equivalent summed over the four measurements did not exceed 15-20 $\mu$ Sv.

In the second phase of the study lead was measured sequentially in tibia, calcaneus, and ulna by the group in Helsinki in the four scrap metal workers. Similarly, in the third part of the study, in vivo concentrations of bone lead measurements were made only by the Helsinki group, in this case in tibia and calcaneus only. This involved workers at the second factory (34 current and seven former lead workers and 16 office workers), together with four of the control group.

\section{Results}

EXPOSURE TO LEAD

Table 1 shows parameters reflecting exposure to lead in the four different exposure groups. It should be noted that not all data are reported for each parameter. In most cases this was due to incomplete data collection: for example, in phases 2 and 3 of the study measurements of lead concentrations in the sternum were not made, hence the lower number of observations in each exposure category. For $\mathrm{BPb}_{\mathrm{int}}$ it was not possible to construct an adequate history of previous blood lead measurements for these former workers. It was also necessary to exclude a few data because they were clear outliers from the main distribution. For example one lead worker had an apparent lead concentration in sternum of $454 \mu \mathrm{g}$ (g bone mineral) ${ }^{-1}$, but his tibia and calcaneus concentrations were each about $25 \mu \mathrm{g}$ ( $\mathrm{g}$ bone mineral $)^{-1}$, and his lead concentration in ulna was $116 \mu \mathrm{g}$ ( $\mathrm{g}$ bone mineral $)^{-1}$; given these data, and the fact that his sternum result was around $8 \sigma$ from the mean of the rest of the results for active workers, it was concluded that contamination, perhaps in lead in hair, had distorted his result. Two ulnar lead measurements were excluded for similar reasons. The final reason for exclusion of data is illustrated by an office worker who had lead concentrations in tibia, calcaneus, sternum, and ulna of $20,140,94$, and $90 \mu \mathrm{g}$ ( $\mathrm{g}$ bone 
Table 2 Correlations coefficients and their significance levels between various exposure parameters among active lead workers

\begin{tabular}{|c|c|c|c|c|c|c|c|c|}
\hline & $U P b$ & $P P$ & $B P b_{\text {eav }}$ & Sternum & Calcaneus & Ulna & Tibia & $B P b_{\text {int }}$ \\
\hline $\mathrm{BPb}$ & $\begin{array}{l}0.610 \\
(86) \\
\star \star \star\end{array}$ & $\begin{array}{l}0.403 \\
(78) \\
\star \star \star\end{array}$ & $\begin{array}{l}0.753 \\
(91) \\
\star \star \star\end{array}$ & $\begin{array}{l}0.504 \\
(53) \\
\star \star \star\end{array}$ & $\begin{array}{l}0.451 \\
(90) \\
\star \star \star\end{array}$ & $\begin{array}{l}0.154 \\
(55) \\
-\end{array}$ & $\begin{array}{l}0 \cdot 250 \\
\underset{\star}{(91)}\end{array}$ & $\begin{array}{l}0.139 \\
(91) \\
-\end{array}$ \\
\hline UPb & & $\begin{array}{l}0.600 \\
(78) \\
\star \star \star\end{array}$ & $\begin{array}{l}0.389 \\
(86) \\
\star \star \star\end{array}$ & $\begin{array}{l}0.395 \\
(53) \\
\star \star\end{array}$ & $\begin{array}{l}0.205 \\
(85) \\
-\end{array}$ & $\begin{array}{l}0 \cdot 162 \\
(51) \\
-\end{array}$ & $\begin{array}{l}0.302 \\
(86) \\
\star \star\end{array}$ & $\begin{array}{l}0.152 \\
(86) \\
-\end{array}$ \\
\hline PP & & & $\begin{array}{l}0.136 \\
(78) \\
-\end{array}$ & $\begin{array}{l}0.251 \\
(53) \\
-\end{array}$ & $\begin{array}{l}0.012 \\
(77) \\
-\end{array}$ & $\begin{array}{l}0.072 \\
(51) \\
-\end{array}$ & $\begin{array}{l}0 \cdot 180 \\
(78) \\
-\end{array}$ & $\begin{array}{l}0.022 \\
(78) \\
-\end{array}$ \\
\hline $\mathrm{BPb}_{\mathrm{ave}}$ & & & & $\begin{array}{l}0.564 \\
(53) \\
\star \star \star\end{array}$ & $\begin{array}{l}0.728 \\
(90) \\
\star \star \star\end{array}$ & $\begin{array}{l}0 \cdot 259 \\
(55) \\
-\end{array}$ & $\begin{array}{l}0.599 \\
(91) \\
\star \star \star\end{array}$ & $\begin{array}{l}0.581 \\
(91) \\
\star \star \star\end{array}$ \\
\hline Sternum & & & & & $\begin{array}{l}0.447 \\
(53) \\
\star \star \star\end{array}$ & $\begin{array}{l}0 \cdot 284 \\
(50) \\
\star\end{array}$ & \begin{tabular}{l}
0.336 \\
\multirow{\star}{\star}{$(53)$}
\end{tabular} & $\begin{array}{l}0.240 \\
(53) \\
-\end{array}$ \\
\hline Calcaneus & & & & & & $\begin{array}{l}0.244 \\
(54) \\
-\end{array}$ & $\begin{array}{l}0.503 \\
(90) \\
\star \star \star\end{array}$ & $\begin{array}{l}0.535 \\
(90) \\
\star \star \star\end{array}$ \\
\hline Ulna & & & & & & & $\begin{array}{l}0.428 \\
(55) \\
\star \star\end{array}$ & $\begin{array}{l}0.439 \\
(55) \\
\star \star \star\end{array}$ \\
\hline Tibia & & & & & & & & $\begin{array}{l}0.667 \\
(91) \\
\star \star \star\end{array}$ \\
\hline
\end{tabular}

${ }^{\star} \mathrm{p}<0.05 ;{ }^{\star \star} \mathrm{p}<0.01 ;{ }^{\star \star \star} \mathrm{p}<0.001$.

$\mathrm{BPb}=\mathrm{Blood}$ lead concentration; UPb = urinary lead concentration; $\mathrm{PP}=$ protoporphyrin $\mathrm{IX}$ concentration; $\mathrm{BPb}$ ave $=$ time weighted average blood lead concentration; $\mathrm{BP}_{\mathrm{int}}=$ integrated blood lead concentration.

Numbers of workers in parentheses.

mineral $)^{-1}$ respectively. These were acceptably self consistent, but they were all high compared to the mean values in that exposure group, so it is likely that this person had had exposure to lead that had not been indicated at the time of the survey. Similarly, one office worker had a $\mathrm{BPb}_{\text {int }}$ value of $30.1 \mu \mathrm{mol} \mathrm{y}^{-1}$ and so could not be considered to be a normal member of this exposure group.

\section{ACTIVE LEAD WORKERS}

Among active lead workers those measures that could be expected to reflect recent exposure, current blood lead $(\mathbf{B P b})$, urinary lead (UPb), and protoporphyrin (PP) concentrations correlated strongly with each other. Table 2 shows the correlations among these and other parameters of lead exposure. The correlations among the bone lead measurements and the integrated blood lead $\left(\mathbf{B P b}_{\text {int }}\right)$ were also mostly significant, with $\mathbf{B P b}_{\text {int }}$, tibia, and ulna more closely associated with each other, and calcaneus and sternum correlating particularly with each other. Current blood lead concentrations correlated strongly with the time weighted average blood lead concentration $\left(\mathrm{BPb}_{\mathrm{ave}}\right)(\mathbf{r}=0.75, \mathrm{p}<0.001)$, which can be viewed as a measure of average intensity of exposure. The $\mathbf{B P b}_{\mathrm{ave}}$ also correlated with bone lead measurements and $\mathrm{BPb}_{\mathrm{int}}$. There was, therefore, a hierarchy of parameters ranging from blood lead reflecting short term exposure, to tibia lead and $\mathrm{BPb}_{\text {int }}$ reflecting cumulative exposure, with calcaneus and sternum intermediate.

The only statistically significant difference in these parameters between men and women was in calcaneal lead concentration (men 81.4 (SD 58.6) $\mu \mathrm{g}$ (g bone mineral $)^{-1}, \mathrm{n}=73$; women 55.8 (SD 31.8) $\mu \mathrm{g}$ (g bone mineral $\left.)^{-1}, \mathrm{n}=17 ; 0.01<\mathrm{p}<0.05\right)$. This difference was not accounted for by a simple difference in exposure, as the mean $\mathrm{BPb}_{\text {int }}$ for women was $0.94 \times$ that for men and their tibial lead was $1.17 \times$ the value for men.

The possibility that smoking could increase lead absorption at work was explored among active male workers, of whom 23 were identified as having never smoked and 40 were current smokers. Their ages and duration of exposure to lead were not significantly different, but there was a somewhat higher time weighted average blood lead concentration for the smokers (1.80 (SD 0.47) v 1.60 (SD 0.43); the significance level for the difference was $p \approx 0 \cdot 1$.

FORMER LEAD WORKERS

Table 1 shows the parameters of lead exposure for 
former workers. The parameters that would be expected to reflect long term exposure-that is, the bone lead values-were significantly higher, with the exception of values for the ulna, in the former workers than in either the office workers or in the control group.

Protoporphyrin IX concentration, however, which was raised in the active lead workers, was the same in the former workers as in the office workers and the controls. This confirms that these former lead workers were no longer exposed to lead above normal environmental concentrations. It is noteworthy, therefore, that both the blood and urinary lead concentrations, although lower than in the active workers, were significantly raised when compared with the office workers and the controls. This implies strongly that the skeleton acts as a principal endogenous source of lead for these workers no longer currently exposed to lead. The effect is further shown by the correlations between blood lead and $\mathrm{BPb}_{\text {int }}$, tibial lead, and calcaneal lead concentrations (table 3). Figures 3 and 4 show concentrations of lead in blood and urine as functions of tibial and calcaneal lead respectively. For blood lead a clear trend was seen; it is also apparent that the relation for urinary lead concentrations are heavily influenced by the result of one person, marked with a square in the figure. The regression lines for these relations are as follows with those for urine calculated with the "square" value excluded.

$$
\begin{array}{ll}
\mathrm{BPb}=0.00668 \times \text { tibia }+0.372 & (\mathrm{r}=0.77) \\
\mathrm{UPb}=0.000534 \times \text { tibia }+0.0382 & (\mathrm{r}=0.74) \\
\mathrm{BPb}=0.00348 \times \text { calcaneus }+0.332 & (\mathrm{r}=0.67) \\
\mathrm{UPb}=0.000229 \times \text { calcaneus }+0.0391 & (\mathrm{r}=0.53)
\end{array}
$$

Concentrations of lead in blood and urine are in $\mu \mathrm{mol}$ $1^{-1}$ and the bone lead measurements are in $\mu \mathrm{g}$ ( $\mathrm{g}$ bone mineral $)^{-1}$. The intercept values for blood and urine (effectively the estimated lead concentration in the absence of any contribution from bone) are comparable with the mean values found in the office workers and somewhat higher than those seen in the control group.

\section{DIFFERENCES AMONG EXPOSURE SUBGROUPS}

Table 1 shows the results of statistical tests for differences in mean values of the parameters for the different exposure groups. Concentrations of lead in blood and urine were different in each group, with blood distinguishing best between groups. Integrated blood lead concentration was higher in the former than in the current lead workers, but the difference was not statistically significant at the $5 \%$ level. Of the four bone lead measurements only ulna showed a significant difference between active and former workers, and ulna lead values were similar in all three groups not currently exposed to lead: this was surprising, especially considering that in nine of

\begin{tabular}{|c|c|c|c|c|c|c|c|c|}
\hline & $U P b$ & $P P$ & $B P b_{\text {ave }}$ & Sternum & Calcaneus & Ulna & Tibia & $B P b_{i n t}$ \\
\hline $\mathrm{BPb}$ & $\begin{array}{l}0 \cdot 757 \\
(16) \\
\star \star \star\end{array}$ & $\begin{array}{l}0.415 \\
(16)\end{array}$ & $\begin{array}{l}0.861 \\
(13) \\
\star \star \star\end{array}$ & $\begin{array}{l}0.323 \\
(9) \\
-\end{array}$ & $\begin{array}{l}0.667 \\
(16) \\
\star \star\end{array}$ & $\begin{array}{l}0.616 \\
(8) \\
-\end{array}$ & $\begin{array}{l}0.774 \\
(16) \\
\star \star \star\end{array}$ & $\begin{array}{l}0.550 \\
(13) \\
-\end{array}$ \\
\hline $\mathrm{UPb}$ & & $\begin{array}{l}0.665 \\
(16) \\
\star \star\end{array}$ & $\begin{array}{l}0.719 \\
(13) \\
\star \star\end{array}$ & $\begin{array}{l}0.481 \\
(9) \\
-\end{array}$ & $\begin{array}{l}0.357 \\
(16) \\
-\end{array}$ & $\begin{array}{l}0.175 \\
(8) \\
-\end{array}$ & $\begin{array}{l}0.496 \\
(16) \\
-\end{array}$ & $\begin{array}{l}0.237 \\
(13) \\
-\end{array}$ \\
\hline PP & & & $\begin{array}{l}0.323 \\
(13) \\
-\end{array}$ & $\begin{array}{l}0.708 \\
(9) \\
\star\end{array}$ & $\begin{array}{l}0.008 \\
(16) \\
-\end{array}$ & $\begin{array}{c}-0.218 \\
(8) \\
-\end{array}$ & $\begin{array}{l}0 \cdot 254 \\
(16) \\
-\end{array}$ & $\begin{array}{l}0.019 \\
(13) \\
-\end{array}$ \\
\hline $\mathrm{BPb}_{\mathrm{ave}}$ & & & & $\begin{array}{l}0 \cdot 282 \\
(7) \\
-\end{array}$ & $\begin{array}{l}0.683 \\
(13) \\
\star\end{array}$ & $\begin{array}{l}0.391 \\
(6) \\
-\end{array}$ & $\begin{array}{l}0.726 \\
(13) \\
\star \star\end{array}$ & $\begin{array}{l}0.677 \\
(13) \\
\star\end{array}$ \\
\hline Sternum & & & & & $\begin{array}{l}0.478 \\
(9) \\
-\end{array}$ & $\begin{array}{c}-0.102 \\
(8) \\
-\end{array}$ & $\begin{array}{l}0.484 \\
(9) \\
-\end{array}$ & $\begin{array}{l}0.287 \\
(7) \\
-\end{array}$ \\
\hline Calcaneus & & & & & & $\begin{array}{l}0.590 \\
(8) \\
-\end{array}$ & $\begin{array}{l}0.928 \\
(16) \\
\star \star \star\end{array}$ & $\begin{array}{l}0.871 \\
(13) \\
\star \star \star\end{array}$ \\
\hline Ulna & & & & & & & $\begin{array}{l}0.503 \\
(8) \\
-\end{array}$ & $\begin{array}{l}0.299 \\
(6) \\
-\end{array}$ \\
\hline Tibia & & & & & & & & $\begin{array}{l}0.794 \\
(13) \\
\star \star\end{array}$ \\
\hline
\end{tabular}
the $\mathbf{1 6}$ former workers the exposure to lead had only ceased for two years or less. Thus there would have

Table 3 Correlation coefficients and their significance levels between various exposure parameters among former lead workers

For explanations, see footnote, table 2. 

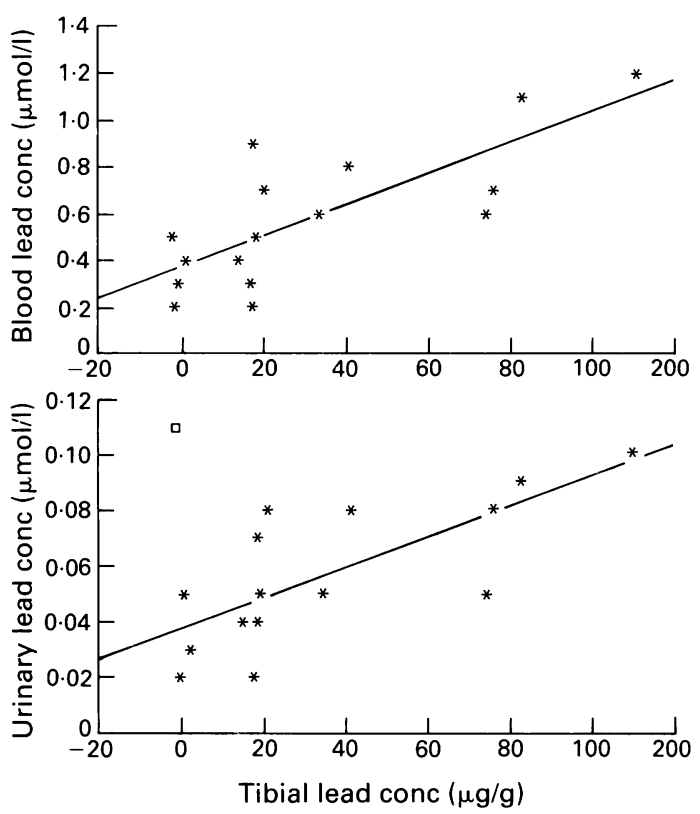

Figure 3 Blood lead and urinary lead concentrations for retired lead workers in relation to their tibial lead concentrations. Outlier is marked by a square.

been insufficient time for the concentrations of ulna lead to have fallen greatly, unless an implausibly short half life were operating.

\section{VARIATIONS IN CONCENTRATIONS OF LEAD IN BONE WITH TIME}

Figure 5 shows an alternative way of considering the relation between lead in different bones and continuing exposure. Here the active lead workers were divided into three groups separated by the 33rd and 67 th percentiles of the integrated blood lead distribution. Lead concentrations are expressed in terms of bone mineral and lead concentrations in the tibia, a bone with high mineral density, appeared lowest. Lead concentrations increased numerically from one exposure group to the next for all bone types but significant differences only existed for tibia lead concentrations between each of the exposure groups. At the other extreme, sternal lead concentration increased little from the second to the third exposure category, perhaps indicating a balance between input from further exposure and output.

As data for ulnar and sternal lead concentrations were limited, the behaviour of lead in tibia and calcaneus was studied more closely, in the manner shown in figs 6 and 7. The active lead workers were divided into nine groups using 33rd and 67th percentiles of the time weighted average blood lead concentrations, reflecting intensity of exposure, and the same percentiles in the duration of exposure. Each row or column contained about 30 observations and the number of observations in each of the nine elements varied from three to 17 .

Significant relations existed for tibia with both duration and intensity of exposure. Calcaneus, however, strongly reflected intensity of exposure in all three duration categories but showed no significant trend with duration of exposure over these periods. Although the relations were in general less strong, the ulna behaved in a similar fashion to the tibia and the sternum was similar to the calcaneus.

\section{RENAL EFFECTS}

No correlation was seen between the parameters reflecting short or long term exposure to lead, and the urinary excretion of $\mathrm{N}$-acetylglycosaminidase or retinal binding protein. All values were within normal limits.

\section{Discussion}

ESTIMATING THE SKELETAL LEAD BURDEN

The percentage of total body burden of lead in bone varies from $86 \%$ to $97 \%$ in adults ${ }^{1}$; this skeletal lead burden thus represents the major body store that could become a continuing endogenous source of lead once external exposure has ceased. An attempt to derive a total body burden requires an assumption about the proportion of lead in each bone, which would increase the uncertainty without improving
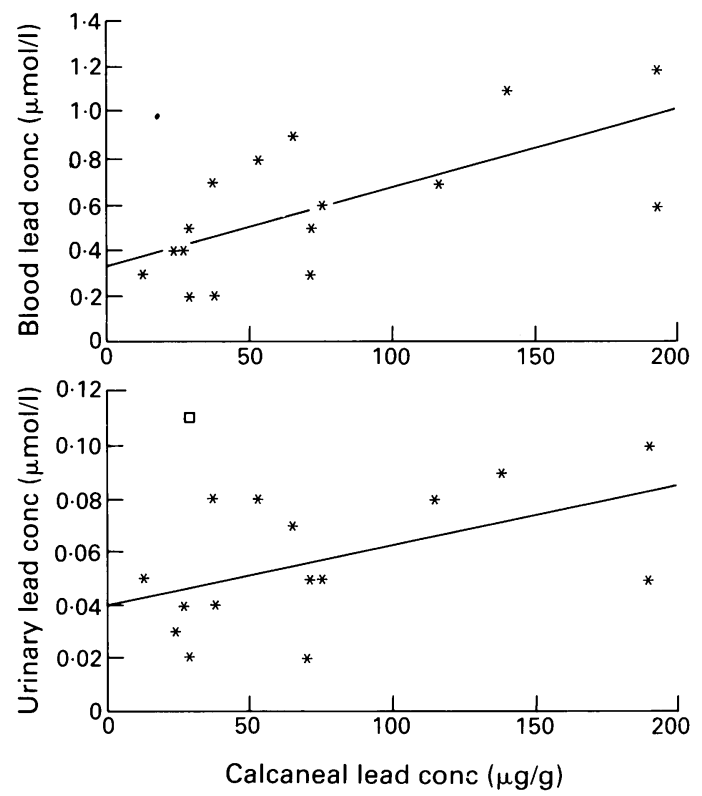

Figure 4 Blood lead and urinary lead concentrations for retired lead workers in relation to their calcaneal lead concentrations. Outlier is marked by a square. 


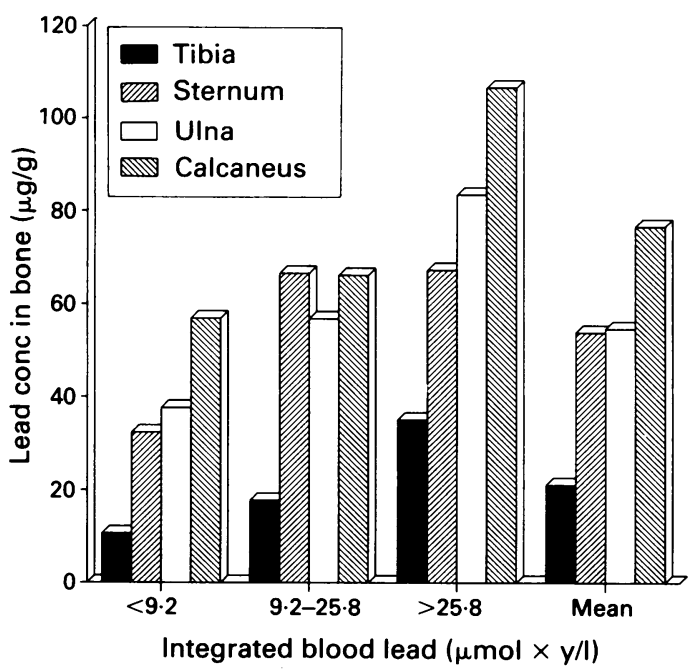

Figure 5 Mean lead concentration in four bones of lead workers exhibiting different integrated blood lead values. Groups were split by 33.3 and 66.6 percentiles of integrated blood lead concentrations.

the value of the information. It is clear that not all bones accumulate and retain lead with the same characteristic half lives, so it is desirable to have data from more than one bone type contributing to an estimate of total skeletal burden. Of the measurements reported here, amounts of lead in tibia and ulna appear to behave similarly with respect to time, but the ulna measurement is much less precise and that measurement was not performed on all subjects. In an analogous fashion, calcaneal and sternal lead behave in much the same way, but the sternum measurement is much the less precise and, again, was not performed on all subjects. The question then arises as to how well lead in the calcaneus might reflect that in trabecular bone as a whole. The strong correlation and similar behaviour of calcaneal and sternal lead in this study is reassuring in this context and there is further evidence provided by the data given by Somervaille $e t a l,{ }^{12}$ in which vertebral lead concentration, assessed by biopsy, correlated strongly with calcaneal lead concentration and had a numerically higher correlation coefficient with calcaneal lead concentration than with duration of exposure, cumulative blood lead index (analogous to $\mathrm{BPb}_{\text {int }}$ here), tibial, or phalangeal lead concentration. For these reasons tibial lead concentration is taken as indicative of the concentration in cortical bone, and calcaneus as representing trabecular bone. Reference $\operatorname{man}^{23}$ has a skeletal mass of $10 \mathrm{~kg}$ of which $4 \mathrm{~kg}$ is cortical wet bone mass and $1 \mathrm{~kg}$ is trabecular wet bone mass. Ashed weights, corresponding closely to bone mineral, are given as $2200 \mathrm{~g}$ and $500 \mathrm{~g}$ respec- tively. On this basis a skeletal lead burden can be calculated as:

$$
\mathrm{Pb}_{\text {skeletal }}=2.2 \times \mathrm{Pb}_{\text {tibia }}+0.5 \times \mathrm{Pb}_{\text {calcaneus }}
$$

where the skeletal lead burden is in mg and the tibial and calcaneal lead concentrations are in $\mu \mathrm{g}$ (g bone mineral $)^{-1}$.

More detailed information is given by Bigler and Woodard ${ }^{24}$ and Woodard and White. ${ }^{25}$ The first reference lists the different components of the human skeleton as proportions of total bone tissue mass, and the second lists the calcium contents of much the same components of the skeleton and gives the calcium content of cortical bone as $22.20 \mathrm{~g}$ per $100 \mathrm{~g}$ wet weight and that of spongiosa (or trabecular bone) as $7.47 \mathrm{~g}$ per $100 \mathrm{~g}$ wet weight in adults. If the total bone mineral mass is again taken to be $2.7 \mathrm{~kg}$, then:

$$
\mathrm{Pb}_{\text {skeletal }}=1.935 \times \mathrm{Pb}_{\text {tibia }}+0.765 \times \mathrm{Pb}
$$

for men and

$$
\mathrm{Pb}_{\text {skeletal }}=1.951 \times \mathrm{Pb}_{\text {tibia }}+0.749 \times \mathrm{Pb}
$$

for women; in both cases the units are as in equation (7).

A fourth possible approach is to consult the data of Wittmers $e t a l^{26}$ as they list the lead content of five bone sites. They also compare skeletal lead burden estimated from the five sites with that estimated from tibia alone and with that based on measuring the tibia, predicting the other four site concentrations of lead, and then computing total skeletal burden. They conclude that the maximum deviation between an estimate based on a simple tibia measurement and that based on measurement at five sites is about $13.5 \%$ for the age group $21-35$ and that this decreases with increasing age, with the possible exception of subjects over 75 years old (not applicable in this study). Their approach would, however, require three separate equations to cover the age ranges encountered in this study which, together with their reassuring conclusion as to the usefulness of more restricted data, meant that this option was not pursued. The use of the data of Bigler and Woodard ${ }^{24}$ and Woodard and White ${ }^{25}$ was appealing; however, it necessitated using their tabulated values in a way for which they were not designed. So equation (7) was used for further analysis.

Table 4 summarises the skeletal lead burdens thus calculated. The groups occupationally exposed to lead were well separated from both the office workers and the controls, and these two groups differed significantly from each other at the $5 \%$ level. The statistical power was thus, not surprisingly, intermediate between that of tibia and that of calcaneus. The magnitude of these skeletal lead values are low compared with those reported by Barry. ${ }^{1}$ His mean body burden of lead in non-occupationally exposed adult men was $165 \mathrm{mg}$, of which roughly $94 \%$ was in bone. This is about double that found in our active 


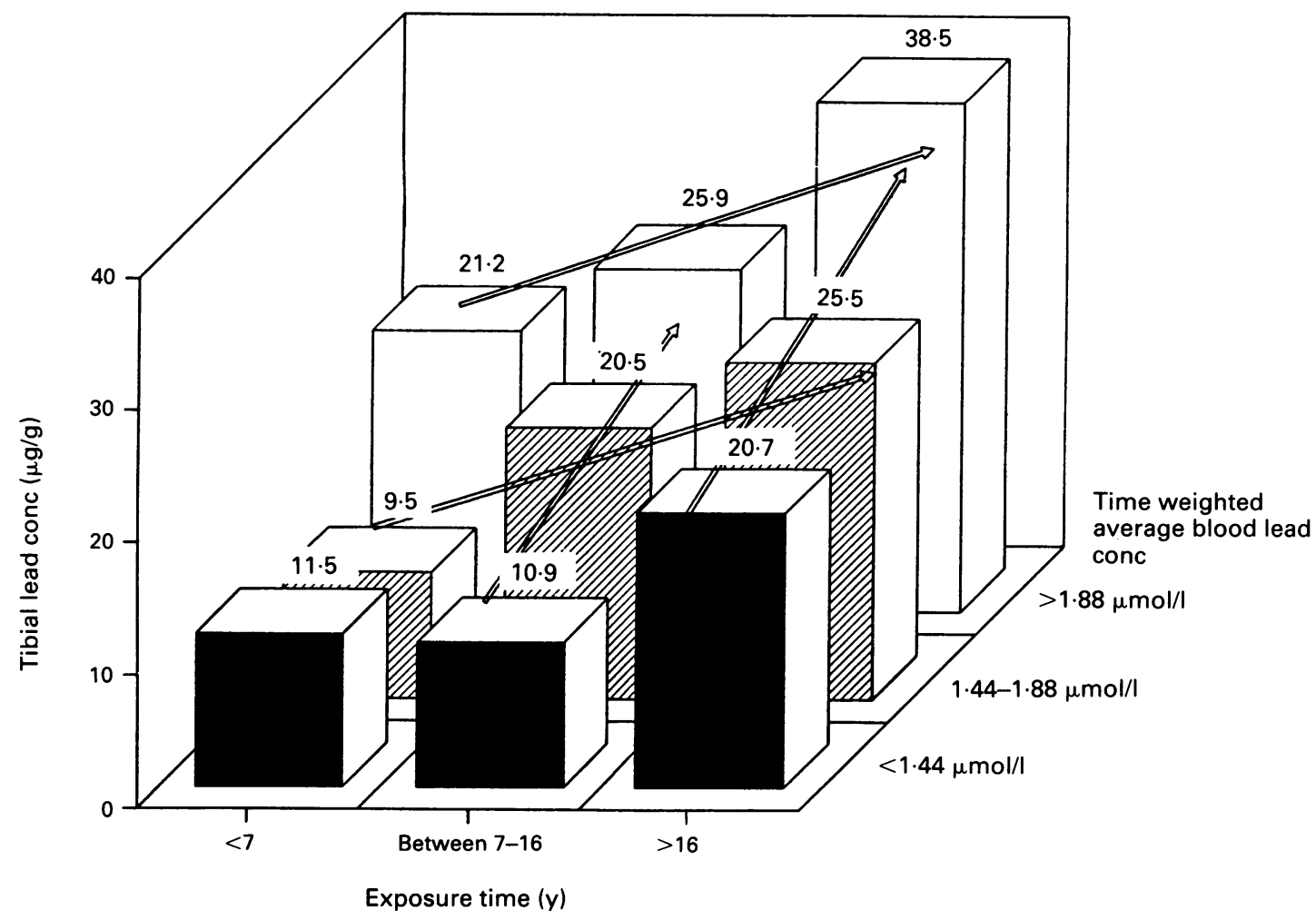

Figure 6 Tibial lead concentrations in groups of lead workers divided according to their duration and intensity of lead exposure or time weighted average blood lead concentration. Group divisors are 33.3 and 66.6 percentiles. Statistically significant trends are marked by arrows.

lead workers and some 20 times the value for the controls. The mean body burden for occupationally exposed lead workers described by Barry was $566 \mathrm{mg}$ and ranged up to $12692 \mathrm{mg}$. On close examination, the difference is seen to be largely reflected in measurements of tibia lead concentration, an important contributor to Barry's burden estimate as it is in our equation (7). Barry's non-occupationally exposed adults, aged 20 years and over (57 of the 60 subjects contributing to the mean body burden value of $165 \mathrm{mg}$ ), had a mean tibial lead concentration of $24.3 \mu \mathrm{g}$ (g wet bone) $)^{-1}$, which equates to about $43 \mu \mathrm{g}$
( $\mathrm{g}$ bone mineral) $)^{-1}$ (the units we used). This is about double the mean value for tibial lead concentration in the active workers in our study and more than 10 times that of the control group.

The mean blood lead values are also different between our different groups, and between our data and those of Barry; however, the differences in concentrations of blood lead were not as great as those for the skeletal burden, suggesting that the use of measurements of blood lead concentrations with an assumption of steady state exposure conditions might seriously underestimate lead body burden.

Table 4 Skeletal lead burdens in different exposure categories calculated according to equation (7)

\begin{tabular}{|c|c|c|c|c|c|c|}
\hline \multirow{2}{*}{$\begin{array}{l}\text { Lead workers } \\
\begin{array}{l}\text { Mean }(S D) \\
m g \\
n\end{array}\end{array}$} & \multicolumn{2}{|c|}{ Former lead workers } & \multicolumn{2}{|c|}{ Office workers } & \multicolumn{2}{|l|}{ Controls } \\
\hline & $\begin{array}{l}\text { Mean }(S D) \\
m g \\
n\end{array}$ & $\begin{array}{l}\text { Significance } \\
\text { level }\end{array}$ & $\begin{array}{l}\text { Mean }(S D) \\
m g \\
n\end{array}$ & $\begin{array}{l}\text { Significance } \\
\text { level }\end{array}$ & $\begin{array}{l}\text { Mean }(S D) \\
m g \\
n\end{array}$ & $\begin{array}{l}\text { Significance } \\
\text { level }\end{array}$ \\
\hline $85 \cdot 5(56 \cdot 2)$ & $107 \cdot 9(104 \cdot 1)$ & - & $24.0(27 \cdot 7)$ & $\star \star \star \star$ & $7 \cdot 8(26 \cdot 6)$ & $\star \star \star$ \\
\hline 90 & 16 & & 38 & $t+t$ & 26 & $\stackrel{t \dagger}{\ddagger}$ \\
\hline
\end{tabular}

Significance levels; ${ }^{\star} \mathrm{p}<0.05 ;{ }^{\star \star} \mathrm{p}<0.01 ;{ }^{\star \star} \mathrm{p}<0.001$ for differences of means from mean of lead workers group. Similarly $\dagger$ for differences of means from former lead workers' group and $\ddagger$ for differences of means from office workers’ group. $\mathrm{n}=$ Number of observations. 


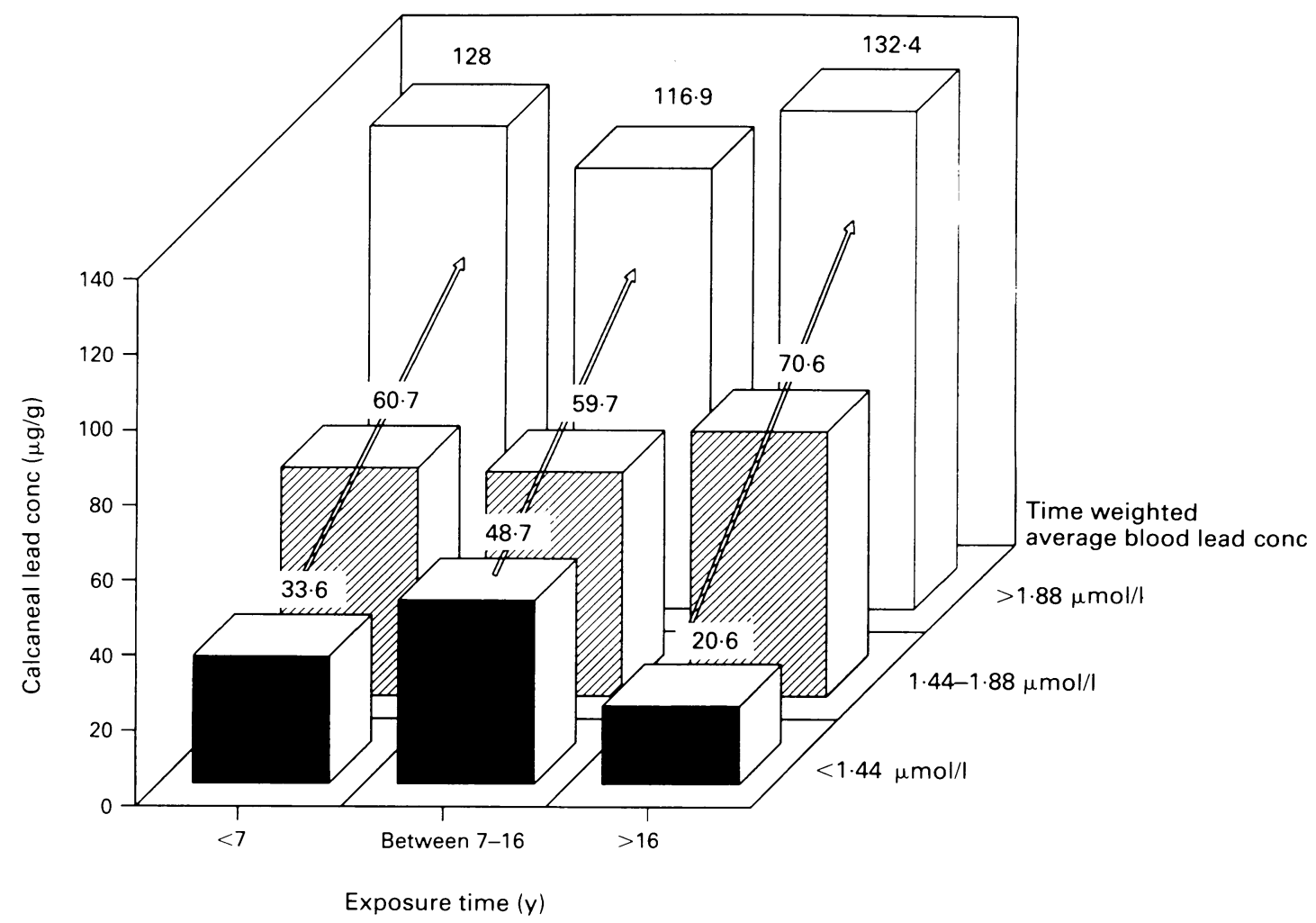

Figure 7 Calcaneal lead concentration in groups of workers divided according to their duration and intensity of lead exposure or time weighted average blood lead concentration. Group divisors are $33 \cdot 3$ and $66 \cdot 6$ percentiles. Statistically significant trends are marked by arrows.

\section{LEVELS OF LEAD EXPOSURE}

The exposures encountered by workers in this study were modest by comparison with some others reported,${ }^{11}$ for both current and cumulative exposure. The mean blood lead value among active lead workers was $1.45 \mu \mathrm{mol} 1^{-1}$ compared with $2.48,1.56$, and 2.32 $\mu \mathrm{mol}^{-1}$ at three factories surveyed by Somervaille et al. ${ }^{11}$ The mean tibial lead concentration for active workers was $21 \cdot 1 \mu \mathrm{g}$ (g bone mineral $)^{-1}$ compared with $54 \cdot 8,32 \cdot 3$, and $31 \cdot 0 \mu \mathrm{g}$ (g bone mineral $)^{-1}$ at the three English factories. The duration of exposure at the second and third English factories was about $50 \%$ longer than here, however, so past amounts of exposure may not have reflected the apparent difference in current practice; this contention is supported by the higher mean tibia concentration of $32 \cdot 4$ $\mu \mathrm{g}$ (g bone mineral) $)^{-1}$ seen among the former lead workers in this study.

The degree of lead exposure was clearly higher among office workers than among controls, as is shown by their significantly higher blood and urinary lead concentrations.
Apart from ulna, the bone lead concentrations were all higher among office workers than controls; in the case of calcaneus and sternum significantly so. Therefore the somewhat raised exposure amongst staff employed at the lead factories but not actively engaged on lead related work was a consistent feature of these workplaces. This additional exposure could have arisen from slight contamination of the entire factory site or from occasional visits to the production areas.

The control group exhibited very low values for all the parameters reflecting either current or cumulative lead exposure. Indeed, concentrations were often so low that the results were only interpretable on a group mean basis. That environmental exposure to lead is slight in Finland is reinforced by comparison with the concentrations found in an almost analogous control group drawn from English university staff. ${ }^{.1}$ There the mean blood lead concentration was 0.63 $\mu \mathrm{mol} 1^{-1}$ and the tibial lead concentration was $16.7 \mu \mathrm{g}$ ( $\mathrm{g}$ bone mineral $)^{-1}$, three to five times the corresponding concentrations in Finland. 
MEASUREMENTS AT DIFFERENT BONE SITES

The data reported by Somervaille et al ${ }^{12}$ raised the possibility that the calcaneus was in some fashion an atypical trabecular bone, and thus was handling lead in a manner not representative of this type of bone in the body as a whole. In this context, the strong correlation between sternal lead and calcaneal lead for the 104 subjects in whom both were measured $(r=0.61)$ was reassuring as was the apparently similar behaviour of sternal lead to calcaneal lead with regard to intensity and to duration of exposure. The uncertainties on sternum lead measurements were about double those on calcaneal lead measurements, however, and, as can be seen from table 1, the power to distinguish among different exposure groups was weaker. Similarly, ulnar lead measurements carried nearly three times the uncertainty of tibial lead measurements, which they otherwise resembled, especially in their pattern of correlations in both the active and former lead workers. More puzzling was the near identity of mean ulnar lead concentrations in all groups other than the active lead workers. The possibility of superficial contamination or an instrumental offset in the measurement procedure cannot be entirely excluded, but such factors would in no way explain the strong correlations with, for example, tibial lead concentration or $\mathrm{BPb}_{\text {int }}$. It is concluded, however, that future work should concentrate on measurements of tibial and calcaneal lead concentrations.

LEAD METABOLISM IN CORTICAL AND TRABECULAR BONE The data presented in figs 6 and 7 show a noticeable contrast between the behaviour of tibial lead and that of calcaneal lead as a function of time. Tibial lead concentration increased both as a function of intensity of exposure and as a function of duration of exposure. This pattern is consistent with the reported behaviour of tibial lead as an index of cumulative exposure. ${ }^{11}$

Calcaneal lead concentration, by contrast, was strongly dependent on intensity of exposure rather than duration of exposure (fig 7). This indicates that the biological half life of lead in calcaneus was short compared with the seven to eight year periods into which the duration of exposure was split. In fact the mean calcaneal values in the three exposure duration groups were 60,60 , and $100 \mu \mathrm{g}$ ( $\mathrm{g}$ bone mineral $)^{-1}$ and the corresponding mean durations of exposure were $3 \cdot 2,11 \cdot 8$, and $21 \cdot 2$ years, so it is not readily possible from these data to estimate a half life. Further evidence for a difference between lead metabolism in cortical and in trabecular bone is provided by the gradation in ratios of the relevant parameters in former and active lead workers. That for integrated blood lead (presumably independent of any metabolically related half life) was 1.67 (SD 0.38), for tibial lead 1.54 (SD 0.46), and for calcaneal lead 0.96 (SD $0 \cdot 21$ ). The simplest interpretation of these figures is as evidence of some sort of more rapid equilibration of lead in calcaneus than of lead in tibia. The same inference can be drawn from the necropsy based data. $^{26}$

\section{ENDOGENOUS EXPOSURE TO LEAD}

This phenomenon has been studied previously and reported by Schütz et $a l^{27}$ and Christoffersson et $a l,{ }^{28}$ who made serial measurements on a group of workers retired from the lead industry. Schütz et al found that skeletal lead can maintain blood lead at a concentration as high as $1.8 \mu \mathrm{mol} 1^{-1}$. The findings in this study are consistent with these earlier findings in that the highest blood lead concentration among the former lead workers here was $1.2 \mu \mathrm{mol} 1^{-1}$. An estimate can be made of the bone lead concentrations that would be expected to produce endogenous exposure resulting in given increased blood lead concentrations. If an arbitrary total blood lead value of $1 \mu \mathrm{mol} 1^{-1}$ is taken for illustration, the corresponding tibial and calcaneal lead concentrations are 94 and $192 \mu \mathrm{g}$ ( $\mathrm{g}$ bone mineral) ${ }^{-1}$ respectively, using equations (3) and (5). This corresponds to an estimated skeletal lead burden of $303 \mathrm{mg}$. Alternatively the regression equation of blood lead $v$ skeletal burden amongst former workers can be fitted. This results in:

$$
\mathrm{BPb}=0.00218 \times \mathrm{SB}+0.352(\mathrm{r}=0.76)(10)
$$

Table 5 Regression equations with SD and correlation coefficient ( $r$ ) of tibial and calcaneal lead and body burden $v$ BPb $b_{\text {int }}$ for lead and former lead workers. Linear relations between tibial and calcaneal lead concentrations are also given

\begin{tabular}{|c|c|c|c|}
\hline \multirow[t]{2}{*}{ Dependent variable } & \multicolumn{2}{|c|}{ Independent variable } & \multirow[b]{2}{*}{$r$} \\
\hline & Slope (SD) & Intercept $(S D)$ & \\
\hline $\begin{array}{l}\text { Tibial lead }\left(\mathrm{mg} \mathrm{kg}^{-1}\right) v \mathrm{BPb}_{\text {int }} \\
\text { Calcaneal lead }\left(\mathrm{mg} \mathrm{kg}^{-1}\right) v \mathrm{BPb}_{\text {int }} \\
\text { Lead body burden }(\mathrm{mg}) v \mathrm{BPb}_{\text {int }} \\
\text { Tibial lead }\left(\mathrm{mg} \mathrm{kg}^{-1}\right) v \text { calcaneus }\end{array}$ & $\begin{array}{ll}\text { Lead workers } \\
0.57 & (0.07) \\
1.51 & (0.26) \\
2.00 & (0 \cdot 22) \\
0.15 & (0.03)\end{array}$ & $\begin{array}{rr}9 \cdot 1 & (2 \cdot 0) \\
43 \cdot 6 & (7 \cdot 5) \\
41 \cdot 8 & (6 \cdot 4) \\
9 \cdot 8 & (2 \cdot 6)\end{array}$ & $\begin{array}{l}0 \cdot 66 \\
0.53 \\
0 \cdot 70 \\
0 \cdot 50\end{array}$ \\
\hline $\begin{array}{l}\text { Tibial lead }\left(\mathrm{mg} \mathrm{kg}^{-1}\right) v \mathrm{BPb}_{\text {int }} \\
\text { Calcaneal lead }\left(\mathrm{mg} \mathrm{kg}^{-1}\right) v \mathrm{BPb}_{\text {int }} \\
\text { Lead body burden }(\mathrm{mg}) v \mathrm{BPb}_{\text {int }} \\
\text { Tibial lead }\left(\mathrm{mg} \mathrm{kg}^{-1}\right) v \text { calcaneus }\end{array}$ & $\begin{array}{cl}\text { Former lead workers } \\
1.27 & (0.24) \\
2.17 & (0.37) \\
3.88 & (0.68 \\
0.56 & (0.06)\end{array}$ & $\begin{array}{r}-10 \cdot 8(10 \cdot 5) \\
0.3(16 \cdot 1) \\
-23.5(29 \cdot 7) \\
-9.4(6 \cdot 1)\end{array}$ & $\begin{array}{l}0 \cdot 85 \\
0 \cdot 87 \\
0 \cdot 67 \\
0.94\end{array}$ \\
\hline
\end{tabular}


with $\mathrm{BPb}$ expressed in $\mu \mathrm{mol} 1^{-1}$ and the skeletal burden in $\mathrm{mg}$. This gives a value for skeletal burden, corresponding to $1 \mu \mathrm{mol} 1^{-1}$ of lead in blood, of $297 \mathrm{mg}$. These relations can be explored further by examining the regression relations of tibial and calcaneal lead and skeletal lead burden with integrated blood lead $\left(\mathrm{BPb}_{\text {int }}\right)$. Table 5 lists these. Thus it is possible to derive an estimate of the cumulative exposure in terms of $\mathbf{B P b}_{\text {int }}$ that gives endogenous exposure resulting in a total blood lead concentration of $1 \mu \mathrm{mol} 1^{-1}$ in the low background exposure conditions in Finland. Using the equations in table 5 and the bone and skeletal burden values derived above gives $\mathrm{BPb}_{\text {int }}$ values of 92-95 $\mu \mathrm{mol} \mathrm{y} 1^{-1}$, based on the equations for the former workers, and 100 to $152 \mu \mathrm{mol} \mathrm{y}^{-1}$ using the equations for the active workers. At a constant working exposure at the maximum current Finnish regulatory concentration for blood lead of $2 \cdot 4 \mu \mathrm{mol} 1^{-1}$, exposure durations of between 38 and 63 years would be required to produce a blood lead concentration of $1 \mu \mathrm{mol} \mathrm{l}^{-1}$.

\section{Conclusions}

In general the blood lead and bone lead concentrations measured in this study were low compared with the results of similar studies reported previously. ${ }^{10-1229}$ The advent of regular blood lead monitoring, which began in the late $1960 \mathrm{~s}$, had reduced individual exposures and the number of lead poisoning incidents decreased dramatically ${ }^{30}$ (and Anttila A, Sallmén M, Valkonen S, Taskinen $H$, Hemminki K. Unpublished observations.) The low measured values for exposure to lead and accumulation reported here provide clear testimony to the efficacy of the preventive programme. Despite the fact that occupational lead poisoning is now uncommon, unanswered questions remain as to possible effects of low long term exposure on central and peripheral neurological function. ${ }^{6}$ The present study does not support the notion of the severe toxicity of lead at low exposure. Lead causes some, albeit temporary, impairment of haem biosynthesis, even at the current low exposure. It is also becoming increasingly clear that endogenous exposure to lead arising from skeletal burdens accumulated over a working lifetime can easily produce the dominant contribution to systemic lead concentrations once occupational exposure has ceased. Although such exposures found here were not exceptional, and the current exposures in these Finnish factories do not give rise to immediate concern, this phenomenon should be further quantified as, where exposures are higher or where a sudden change in bone metabolism may cause a rapid mobilisation of significant quantities of lead, this type of exposure could constitute a hazard.
Requests for reprints to: Dr J Erkkilä, Instrumentarium Imaging/MRI, PO Box 357, SF-00101 Helsinki, Finland.

Recent addresses: R Armstrong, Department of Physics, University of Warwick, Coventry CV4 7AL, England; D R Chettle, Department of Physics and Astronomy, McMaster University, 1280 Main Street West, Hamilton, Ontario L8S 4MI, Canada; L Somervaille, Institute of Public and Environmental Health, University of Birmingham, Birmingham B15 2TT, England; B Kock, Uusimaa Hospital District, SF-02770 Espoo, Finland.

We are indebted to Ms Sinikka Vepsä, Ms Anja Leppänen, and Ms Anneli Mäkelä, company occupational health nurses, who facilitated the running of the study. We also thank company doctors Rolf W Ahlberg and Seppo Hakomaa for encouragement and support, and the volunteers from Akkuteollisuus Ltd and Pakkasakku Ltd for their unfailing committment. Ms Sinikka Valkonen supervised the analytical work on blood and urinary lead as well as blood protoporphyrin IX, and Ms Helena Kivistö and Ms Outi Tupasela were in charge of the urinary protein determinations. The study was supported by the Finnish Work Environment Fund.

1 Barry PSI. A comparison of concentrations of lead in human tissues. Br J Ind Med 1975;32:119-39.

2 Rabinowitz MB, Wetherill GW, Kopple JD. Kinetic analysis of lead metabolism in healthy humans. J Clin Invest 1976; 58:260-70.

3 World Health Organisation. Recommended health-based limits in occupational exposure to heavy metals. Geneva: WHO, 1980. (WHO tech rep ser 647.)

4 Seppäläinen AM, Hernberg S. Subclinical lead neuropathy. Am $J$ Ind Med 1980;1:413-20.

5 Haenninen H, Hernberg S, Mantere P, Vesanto R, Jalkanen M. Psychological performance of subjects with low exposure to lead. J Occup Med 1978;20:683-9.

6 Landrigan PJ. Toxicity of lead at low dose. $\mathrm{Br} \mathrm{J}$ Ind Med 1989;46:593-6.

7 Skerfving S, Chistoffersson J-O, Schütz A, et al. Biological monitoring, by in vivo XRF measurements, of occupational exposure to lead, cadmium, and mercury. Biological Tracer Element Research 1987;13:241-51.

8 Marcus AH. Compartmental models with spatial diffusion: estimation for bone seeking tracers. Mathematical Biosciences 1983;64:233-48.

9 Rosen JF. The toxicological importance of lead in bone: The evolution and potential uses of bone lead measurements by $x$-ray fluorescence to evaluate treatment outcomes in moderately lead toxic children. In: Clarkson TW, Friberg L, Norberg GF, Sager PR, eds. Biological monitoring of toxic metals. New York: Plenum Press, 1988:603-21.

10 Christoffersson JO, Schütz A, Ahlgren L, Haeger-Aronsen B, Mattsson S, Skerfving S. Lead in finger-bone analysed in vivo in active and retired lead workers. Am J Ind Med 1984;6: 447-57.

11 Somervaille LJ, Chettle DR, Scott MC, Tennant DR, McKiernan MJ, Skilbeck A, Trethowan WN. In vivo tibia lead measurements as an index of cumulative exposure in occupationally exposed subjects. $\mathrm{Br} J$ Ind Med 1988;45: 174-81.

12 Somervaille LJ, Nilsson $\mathrm{U}$, Chettle $\mathrm{DR}$, et al. In vivo measurements of bone lead-a comparison of two x-ray fluorescence techniques used at three different bone sites. Phys Med Biol 1989;34:1833-45.

13 Batuman V, Edeen RP, Bogden JD, Balestra DJ, Jones KW, 
Sclidlovsky $G$. Reducing bone lead content by chelation treatment in chronic lead poisoning: an in vivo $\mathrm{x}$-ray fluorescence and bone biopsy study. Environmental Research 1989; 48:70-5.

14 Morgan WD, Ryde SJS, Jones SJ, et al. In vivo measurements of cadmium and lead in occupationally exposed workers and in an urban population. International Conference on nuclear analytical methods in the life sciences, Gaithersburg, 1989.

$15 \mathrm{Hu} \mathrm{H}$, Milder FL, Burger DE. X-ray fluorescence measurements of lead burden in subjects with low-level community lead exposure. Arch Environ Health 1990;45:335-41.

16 Tsuchiya K. Lead. In: Friberg L, Nordberg GF, Vouk VB, eds. Handbook on the toxicology of metals. Vol II. Amsterdam: Elsevier, 1986:298-353.

17 Somervaille LJ, Chettle DR, Scott MC. In vivo measurement of lead in bone using x-ray fluorescence. Phys Med Biol 1985;30:929-43.

18 Somervaille LJ, Chettle DR, Scott MC, Aufderheide AC, Wallgren JE, Wittmers LE, Rapp Jr GR. Comparison of two in vivo measurements. Phys Med Biol 1986;31:1267-74.

19 Chettle DR, Scott MC, Somervaille LJ. Improvements in the precision of in vivo bone lead measurements. Phys Med Biol 1989;34:1295-300.

20 Erkkilä J, Paakkari A, Starck J, Riihimäki V. In vivo measurement of lead using XRF. In: Yasumura $S$, Harrison JE, McNeill KG, Woodhead AD, Dilmanian FA, eds. Advances in in vivo body composition studies. New York: Plenum Press, 1990:263-5.

21 Subramanian KS, Meranger JC. A rapid electrothermal atomic absorption spectrophotometric method for cadmium and lead in human blood. Clin Chem 1981;27:1866-71.
22 Herber RFM, Bernard A, Schaler K-H. Standard method for the determination of beta-2 microglobulin, retinol binding protein and albumin in urine. Pure and Applied Chemistry (in press).

23 Snyder WS, Cook MJ, Karhausen LR, Nasset ES, Howells GP, Tipton IH, eds. Report of the task group on reference man. International commission on radiological protection publication No 23. London: Pergamon Press, 1984.

24 Bigler RE, Woodard HQ. Skeletal distribution of mineralized bone tissue in humans. Health Physics 1976;31:213-8.

25 Woodard HQ, White DR. Bone models for use in radiotherapy dosimetry. Br J Radiol 1982;55:277-82.

26 Wittmers Jr LE, Wallgren ME, Alich A, Aufderheide AC, Rapp Jr G. Lead in bone. IV Distribution of lead in the human skeleton. Arch Environ Health 1988;43:381-91.

27 Schütz A, Skerfving S, Ranstam J, Christoffersson J-O. Kinetics of lead in blood after the end of occupational exposure. Scand $J$ Work Environ Health 1987;13:221-31.

28 Christoffersson JO, Ahlgren L, Schütz A, Skerfving S, Mattsson $S$. Decrease of skeletal lead levels in man after the end of occupational exposure. Arck Environ Health 1986;41:312-8.

29 Wielopolski L, Ellis KJ, Vaswani AN, et al. In vivo bone lead measurements: A rapid monitoring method for cumulative lead exposure. Am J Ind Med 1986;9:221-6.

30 Hernberg $S$, Tola $S$. The battle against occupational lead poisoning in Finland. Scand J Work Environ Health 1979; 5:336-44.

Accepted 2 December 1991

\section{Correspondence and editorials}

The British Journal of Industrial Medicine welcomes correspondence relating to any of the material appearing in the journal. Results from preliminary or small scale studies may also be published in the correspondence column if this seems appropriate. Letters should be not more than $\mathbf{5 0 0}$ words in length and contain a minimum of references. Table and figures should be kept to an absolute minimum. Letters are accepted on the understanding that they may be subject to editorial revision and shortening.

The journal now also publishes editorials which are normally specially commissioned. The Editor welcomes suggestions regarding suitable topics; those wishing to submit an editorial, however, should do so only after discussion with the Editor. 